\title{
Educação ambiental e investigações críticas
}

\section{Jorge Sobral da Silva Maia ${ }^{1}$}

1 Doutor em Educação para a Ciência. Professor do Programa de Pós-graduação em Ciência Jurídica da Universidade Estadual do Norte do Paraná - UENP e do Programa de Pós-graduação em Educação Para a Ciência da Universidade Estadual Paulista - UNESP/Bauru.

Resenha de: RODRIGUES, Daniela Gureski; SAHEB, Daniela (org.s). Investigações em educação ambiental. Curitiba: Editora CRV, 2018.

Ao realizarmos uma busca por obras que discutam a educação ambiental crítica no estado do Paraná, encontrei a obra de Investigações em educação ambiental das autoras Daniela Gureski Rodrigues e Daniele Saheb que aborda esta relevante temática no momento atual, por dois motivos, a princípio, os vintes anos da Política Nacional de Educação Ambiental e a urgência da apresentação de estudos qualificados neste vasto campo teórico e prático da educação.

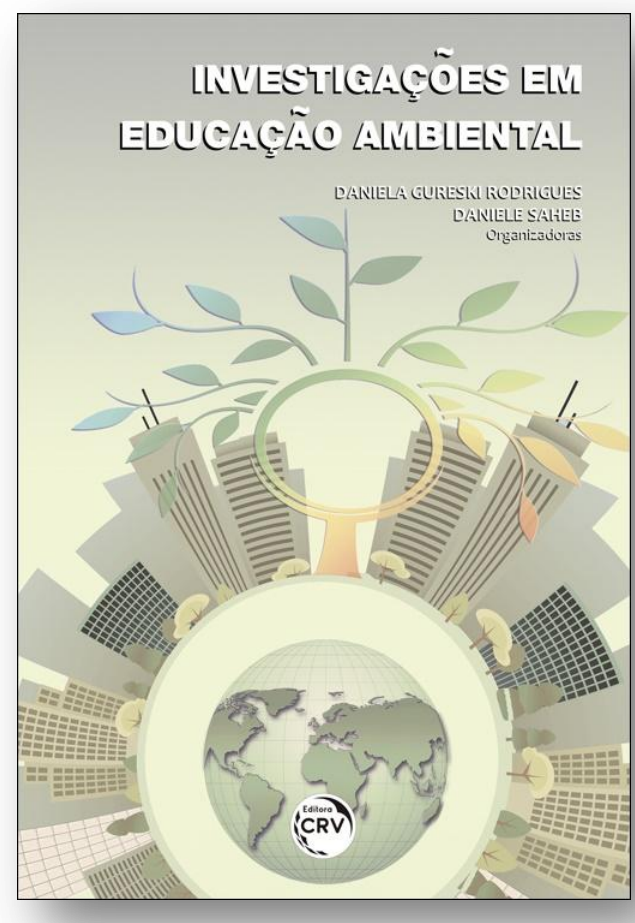

O livro é resultado de uma combinação de textos de autores brasileiros renomados na área em questão. As organizadoras partem da afirmação de que há um consenso geral de que estamos vivendo uma crise ambiental já reconhecida pelos acadêmicos e divulgada pela mídia. Entretanto, argumentam que este reconhecimento não é suficiente para mudanças significativas, no que diz respeito a degradação ambiental, bem como do reconhecimento do ser humano como parte integrante do ambiente. Este aspecto parece fundamental, pois indica que é preciso um diálogo aprofundado com a prática social das comunidades em geral e diagnosticar caminhos para ampliar o grau de comprometimento com a preservação e conservação da natureza para a conquista da sustentabilidade socioeconômica e ambiental.

As autoras organizadoras ainda defendem a necessidade de repensar e reorientar a dinâmica na qual a sociedade se insere fundada num pensamento linear, de ordem excludente, determinista, objetivo, controlador que é herança da ciência moderna. $O$ entendimento do papel da ciência moderna como agente das mazelas da sociedade contemporânea é problematizado por Maia (2015) que aponta outros elementos para a crise socioambiental, como por exemplo, o pragmatismo político, o neoliberalismo na economia e a pós-modernidade na cultura e na educação. 
As autoras apontam também a urgência de buscar a superação do paradigma newtoniano/cartesiano, para um paradigma condizente com realidade complexa que se apresenta. Entendem relevantes as reflexões que se pautem no reconhecimento e valorização das diferentes culturas, bem como a participação de diferentes povos nas decisões essenciais para a manutenção da vida, além de compreender a importância da coletividade para o bem comum visando a romper com a lógica da acumulação econômica e repensar a relação da sociedade com o ambiente.

O capítulos ser dividem por enfoques distintos sendo que os três primeiros buscam o diálogo com a perspectiva crítica da educação ambiental.

$\mathrm{Na}$ linha crítica encontramos o texto de Carlos Frederico Bernardo Loureiro que aborda elementos epistemológicos, ontológicos, metodológicos e históricos da educação ambiental com fundamento no materialismo histórico-dialético com vistas à compreensão da educação ambiental crítica no Brasil. (LOUREIRO, 2004).

Seguindo a mesma orientação teórica Lucas André Teixeira, Marcela de Moraes Agudo, Marília Freitas de Campos Tozoni-Reis propõem um debate sobre a Educação Ambiental crítica na escola em seus diversos níveis, configurando uma discussão relevante para o campo da educação ambiental crítica.

Também se verifica uma articulação de autores como Adriana Massaê Kataoka, Ynaê Martins Osternach, Elizabete França, Ana Lucia Suriani e Affonso Jocimara Peretiako que discutem os limites e as potencialidades da Educomunicação socioambiental como ferramenta da Educação Ambiental (EA) no contexto escolar como forma de enfrentar as fragilidades nas práticas escolares ao adotarem perspectivas conservadoras e pragmáticas da educação ambiental na escola. Parece-nos que a escolha da Educomunicação como componente pedagógico da educação ambiental crítica se justifica, segundo os autores, por "ambas possuírem características comuns, podendo potencializar os resultados e ações intervencionistas na escola no sentido de instrumentalizar e empoderar os participantes para transformação da relação sociedade e natureza, por meio de processos comunicativos associados à educação ambiental. Ainda acreditam os autores, na possibilidade de contraponto em relação à vertente conservacionista e pragmática da educação ambiental.

Também é possível encontrar significativa análise da política pública de Educação Ambiental no trabalho do Coordenador Pedagógico das escolas investigadas pelos pesquisadores Gerson Luiz Buczenko e Maria Arlete Rosa com o intuito de avaliar as aproximações existentes entre a Política Pública atual de Educação Ambiental, e a realidade escolar observada. Os autores apontam que as práticas socioambientais na escola refletem em parte a política pública de Educação Ambiental, no entanto, isso ocorre de forma fragmentada, em razão de não unir a gestão, o currículo e o espaço físico no sentido de se buscar uma escola sustentável. Exibindo a fragilidade da inserção da política pública no ambiente educacional com já discutido em Janke (2012).

Atrelados a uma problemática metodológica Mauro Guimarães e Vicente Pinto debruçam-se sobre a implantação e avaliação de Programas de Educação Ambiental em processos de licenciamento ambiental para empreendimentos de transmissão de energia, por meio da análise, sistematização e integração de dados levantados, a partir de estudos a- 
mostrais com populações de área de influência de empreendimentos de Furnas. Esclarecem que a Educação Ambiental pode ser uma importante estratégia para enfrentar os problemas ambientais oriundos das atividades econômicas que se mostram predatórias em relação ao patrimônio natural e neste sentido, valem-se dela para intervir na realidade impactada por empreendimentos sujeitos a licenciamento, mobilizando a população local para participar ativamente na transformação do seu espaço de vida, por meio de uma gestão socioambiental sustentável de seu território e monitorar os projetos socioambientais decorrentes dos condicionantes do licenciamento.

A obra traz também um texto apresentado de Daniela Gureski Rodrigues, Giovana Dorox, Chrizian Oliveira, Fabiana Juraszek e Daniele Saheb, pesquisadoras que buscaram analisar a contribuição do ensino da Condição humana proposto por Edgar Morin para a inserção da educação ambiental na Educação infantil. As autoras consideram esta etapa da educação como a fase do processo formativo de maior importância no desenvolvimento humano, no que diz respeito às dimensões intelectual e moral. Desta forma compreendem que a educação ambiental articulada à Educação Infantil pode acarretar mudanças de pensamentos e atitudes, por meio de valores ambientais levando a novas posturas das pessoas em relação ao que está a sua volta como defende Carvalho (2006).

Verifica-se que a obra contribui para a compreensão e para a difusão da educação ambiental nas diversas vertentes críticas, possibilitando diálogos profícuos com outras áreas do conhecimento, instigando pesquisas, análises e apontando perspectivas teóricometodológicas e práticas didático-pedagógicas para o vasto e fundamental campo do conhecimento educativo ambiental brasileiro.

\section{REFERÊNCIAS}

CARVALHO, I. C. de M. Educação ambiental: a formação do sujeito ecológico. São Paulo: Cortez, 2006.

JANKE, N. Política nacional de educação ambiental: contradições e disputas. Tese (Doutorado em Educação Para a Ciência). Programa de Pós-graduação em Educação Para a Ciência. Faculdade de Ciências. UNESP - Bauru, 2012.

LOUREIRO, C. F. B. Trajetórias e fundamentos da educação ambiental. São Paulo: Cortez, 2004.

MAIA, Jorge S. da S. Problemáticas da Educação Ambiental no Brasil: elementos para a reflexão. Rev. Eletrônica Mestr. Educ. Ambient. V. 32, n.2, p. 283-298, jul./dez. 2015. 